\title{
What's Next for Green Human Resource Management: Insights and Trends for Sustainable Development
}

\author{
Muhammad Hamza Khan, Syaharizatul Noorizwan Muktar* \\ Department of Business Administration, Azman Hashim International Business School, Universiti Teknologi Malaysia, Johor \\ Bahru 81310, Malaysia
}

Corresponding Author Email: izatul@utm.my

https://doi.org/10.18280/ijsdp.160119

Received: 2 December 2020

Accepted: 26 January 2021

\section{Keywords:}

green human resource management, Sustainable development, environmental management, systematic review, Scopus

\begin{abstract}
The theme of green human resource management (GHRM) has got immense attention among researchers and professionals due to its potential to pacify environmental needs and simultaneously allowing firms to have win-win situation, hence achieving sustainable competitive edge over their rivals. In this context, a systematic review of 70 articles from the past 12 years (2008-2020) on green human resource management was conducted based on Scopus database in terms of (1) the reflections of green HRM, (2) execution of green HRM, (3) factors of green HRM, (4), Effects of green HRM. Results demonstrated that Green HRM is still in developing phase and a multidimensional paradigm with green training as an important element along with teamwork, management support, green organizational culture are the pioneer factors in ensuring sustainable development both at firm and individual level. Finally, this paper highlights the past, current and future endeavors in green HRM paradigm, sustainable development and serves as a guide for researchers who are new to this novel concept; it will also intensity their understanding about the productive journals, appropriate methodology, underpinning theories, sustainable development and substantial knowledge gaps.
\end{abstract}

\section{INTRODUCTION}

Sustainability has arisen as a major concern in the last 20 years due to environmental deterioration caused by corporate sector $[1,2]$. The corporate sector whether from developing or developed nations are now considering the adoption of sustainable practices [3] and this is due to the fact that corporations work in a highly competitive international market and such sustainable practices could be favorable for corporations in shifting from purely economic to ecological and competitive [4]. In the search of this ecological agenda various researchers like [5-7] draws attention towards the ecological side of the human resource management which is green human resource management. Theses scholars argue that rebooting the HRM functions with green practices could be beneficial for corporate sustainability, competitive edge and to meet sustainable development goals.

Since, the paradigm of Green HRM scholarship has increased during the last 10 years, as one of the core strategies to make corporations more sustainable, this concept gained noteworthy attention among scholars [8-11]. As a result, there is an enormous increase in Green HRM scholarship. Moreover, the increasing attention towards sustainability issues compelled conventional human resource management to entwine green human resource management practices to reduce waste, decreasing the amount of carbon footprints and adopt paper less approach [12]. According to Mishra and Rani [13] the HR can act as bridge to initiate environmental friendly practices. Similar argument was given by Jabbour and Santos [14] who considered that HRM has a great potential if merged with sustainability. Cohen, Taylor [15] and Renwick, Redman [16] also demonstrated the potential benefits of Green HRM in formulating sustainable business policies within an organization.

Although the concept of Green HRM is rising exponentially, however constructing a holistic approach towards this novel concept is needed. Systematic reviews were conducted on this novel paradigm but none of the systematic reviews according to the best of our knowledge were executed which divided the green HRM scholarship into four major foundations. The novelty of this review is that it has explained the past, current and future endeavors based on four major foundations. But presently, this innovative idea is deficient in terms of comprehensive literature reviews based on the questions raised below, therefore complete picture of Green HRM needs to be developed. This review article, contributes to what's next for Green HRM by elaborating insights and trends for sustainable development. The purpose of this systematic review is to explore what has been done and what needs to be done in Green HRM paradigm. Firstly, we debated about the dimensions in green HRM paradigm and from the past twelve years various researchers have explained about the possible dimensions in GHRM literature. Secondly, we identified the applications that are useful for both employees and organizations in order to embrace GHRM. Thirdly, we identified the possible antecedents or factors in executing GRHM. Lastly, we debated on the effects of green HRM and their impact on organizations and employees' outcomes. We extended the previous works in green HRM literature like [17, 18]. Although their work provided a huge support to 
understand the concept of GHRM, however we provided more in-depth understanding of on reflections, applications, major theories, and effects in a deeper manner which previous studies lacked. Specifically, the paper debates the following research questions:

RQ1: What are the dimensions/concepts/Reflections in Green HRM paradigm?

RQ2: What are the applications of Green HRM paradigm?

RQ3: What are the factors of Green HRM paradigm?

RQ4: What are the effects of Green HRM paradigm?

RQ5: How reflections, applications, factors and effects of green HRM lead to sustainable development (will be discussed in the last segment in detail)?

\section{METHODOLOGICAL PROCESS}

The current paper endorses the systematic review method for investigating, encapsulating and drawing conclusions [19] from the existing works on Green HRM. Moreover, the technique adopted is lying on [20-22] line of work which includes four sections, time boundary, selecting the appropriate data base, choosing and categorizing articles.

\subsection{Timing boundary of the papers}

In order to review and evaluate papers, the span of the articles lies between early 2008 till end of 2020. The year of 2008 is considered as the pioneer year when Renwick, Redman [23] launched the concept of "Green Human Resource Management" The 2020 is the end point because the authors want to include the most recent works in Green HRM scholarship.

\subsection{Deciding the database}

Scopus database, one of the pioneer databases in the world incorporating 75 million records, 24,600 titles and 194000 books [24] was selected to get the overall picture of Green HRM paradigm.

\subsection{Choosing and categorization of articles}

In order to execute a systematic review, the study needs a well-planned approach. Firstly, we focused on the various dimensions of GHRM, in this context we focused on those studies that thoroughly discussed conceptualizations and reflections of GHRM. Secondly, we performed in detail checking of the important applications of GHRM like green training, green rewards and compensations etc. Thirdly we looked for the possible factors of GHRM. Finally, the studies which were performed relating to the effects of GHRM were checked. The figure on the right shows the article selection approach. Important keywords were identified relating to Green HRM and then these keywords were inserted into the Scopus database to get the required results. These keywords include title-abs-key ("green human resource") OR title-abskey ("green human resource management") OR title-abs-key ("green human resource management practices") OR title-abskey("GHRM"). Then the Span was reduced and only articles from 2008 to 2020 were considered. The initial searching resulted in 151 articles. Abstracts of 151 articles were thoroughly assessed to identify relevant literature related to Green HRM. Moreover, we also excluded those works that did not address Green HRM scholarship. We also eliminated those studies that use the word "green" as jargon. Finally, 70 papers were selected based on original contribution and clearly defined objectives. These 70 papers were inserted in excel sheet for further analysis and they were classified according to the research questions discussed above. The Figure 1 below shows the complete methodological process.

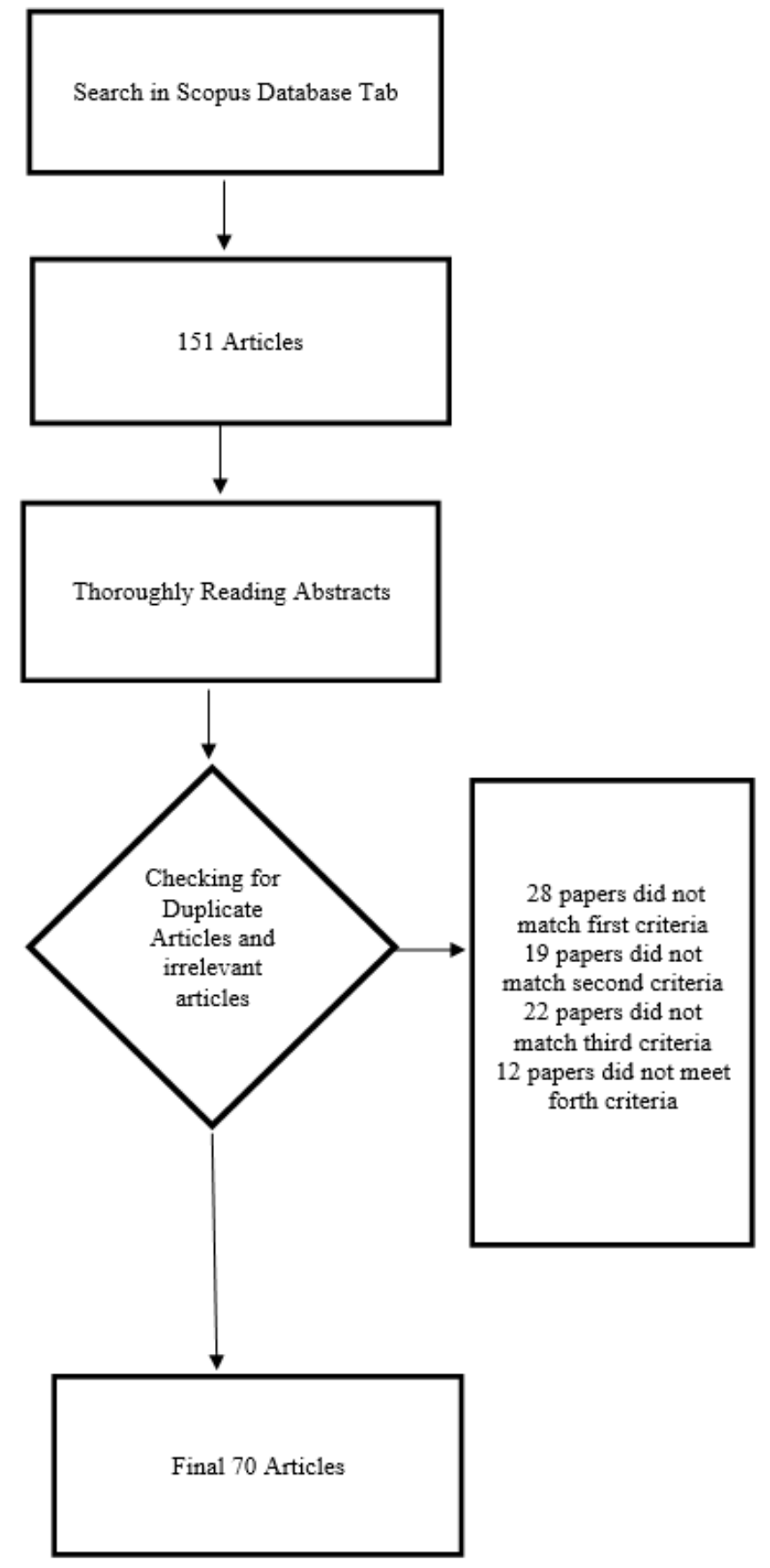

Figure 1. The complete methodological process

The results of 70 articles are classified according to the four research questions in tabular form in Table 1.

\section{RESULTS}

\subsection{Reflections of green HRM: An overview}

Comparatively from other HRM paradigms, the paradigm 
of green HR is recent and novel and various scholars have conceptualized it in variety of reflections. For example, Siyambalapitiya, Zhang [25] gave eight reflections by performing a qualitative study on Green HR, Shah [26] branded seven dimensions and said that it is a multidimensional construct, Mousa and Othman [27] executed a mixed method study and gave three dimensions of Green HRM. Moreover Tang, Chen [28] composed GHRM into six reflections and provided the implications of this novel paradigm at organizational and employee level. In spite of various reflections/ dimension in Green HRM paradigm, literature has unanimously debated six most important reflections which are green recruitment, green selection, green training, green development, green performance management and green rewards and compensation. Contrary to this, the conceptualization of Green HR reflected on various aspects, for instance enhancing environmental performance [29], organizational attractiveness [30], development of employee green behavior [31]. Moreover Jackson, Renwick [5] also conceptualized green HR and indicated to merge its functions with environmental management.

\subsection{Execution/applications of Green HRM: An overview}

Keeble [32], p 16 "Our common Future" defined sustainable development as the "development that meets the needs of the present without compromising the ability of future generations to meet their own needs". Corporations in the 21 century strives for sustainable development goals to reduce environmental contaminations caused by their operations as according to Mishra, Sarkar [33] in order to meet sustainable development goals the execution of Green side of HR is imperative. Similar argument was given Haddock-Millar, Sanyal [34] who said that to achieve environmental sustainability Green HRM practices should be applied. But on the other hand majority of the firms have not fully executed the green HRM practices [35] and among all the reflections on Green HRM as elaborated above green training was mostly executed in various organizations this is because Jabbour [36] considered it as a requirement to pursue environmental management tasks and Zoogah [37] assisted to apply this practice to transform employee behavior into green behavior to meet environmental objectives. On the other hand from the perspective of potential candidates to join green firm Khan and Noorizwan Muktar [30] elaborated that there are psychological and social and contextual processes that shapes employees attitudes. Therefore, the employers and managers must keep in mind that during the recruitment and training of employees these processes must be considered.

\subsection{Factors of Green HRM: An overview}

This segment highlights the factors that are needed to execute green HRM practices. Findings suggests that various studies were performed to determine the executing factors like Hameed, Khan [29] and Tariq, Jan [38] identified green employee empowerment, Yong, Yusliza [39] highlighted on green intellectual capital, Paillé, Chen [40] emphasized on OCBE, Obeidat, Al Bakri [41] stressed on top management support, Moraes Silvana de, Chiappetta Jabbour Charbel [42] considered knowledge management. Moreover Teixeira, Jabbour [43] identified that collaboration, coordination and integration of top management commitment, environmental supportive organizational culture and teamwork are the pioneer factors of green HRM. However most the factors were employee centered therefore organizational centered factors should also be considered.

\subsection{Effects of green HRM: An overview}

The consequences of green human resource management are numerous. Various scholars have identified the effects of this novel paradigm on multiple organizational and employee outcomes and found that green HRM is the foundation of getting competitive advantage and attracting quality employees. For example Khan and Noorizwan Muktar [30] performed empirical study on Malaysian students and found that green HRM is a source of attracting talented candidates, Chaudhary [44] tested a serial mediation model in which green HRM affected students intention to join green firms, Kim, Kim [45] from the employee centered approach studied green HR and found that it positively effects environmental performance and employee green behavior. Saeed, Afsar [46] confirmed that green HRM effects pro environmental behaviors of employees. Shen, Dumont [47] put further light on green HRM scholarship and found that it affects employee intention of not to quit through organizational identification. Moreover various sustainability performance reflections like environmental performance, social performance and economic performance were effected by green HRM paradigm like Hameed, Khan [29] confirmed the enhancing of environmental performance by Green HRM paradigm, similar studies were conducted by $[10,41,48-51]$ to increase organizational performance.

\subsection{Results}

Table 1. Summaries of the studies

\begin{tabular}{|l|l|}
\hline \multicolumn{2}{|c|}{ RQ1: Dimensions/concepts/Reflections of Green HRM } \\
\hline Author & Evident Findings \\
\hline Mousa and Othman [27] & $\begin{array}{l}\text { The results disclosed that the Green HR is a multidimensional concept based on 22 measurement items } \\
\text { reflecting three dimensions, green hiring, green training and involvement, green performance management } \\
\text { and compensation. }\end{array}$ \\
\hline Khan and Muktar [52] & $\begin{array}{l}\text { Worked on bibliometric analysis of green HRM and gave future direction in this field and suggests how } \\
\text { environmental issues can be solved through this novel paradigm. }\end{array}$ \\
\hline Shah [26] & $\begin{array}{l}\text { Outcomes exposed that Green HR has many dimensions, and it is based on 28 items amalgamating seven } \\
\text { dimensions. }\end{array}$ \\
\hline Mukherjee and Chandra [31] & $\begin{array}{l}\text { Conceptualization of Green HR to impact the green behavior of employee. Moreover, a conceptual model was } \\
\text { projected to comprehend and anticipate employee attitude at workplace }\end{array}$ \\
\hline Siyambalapitiya, Zhang [25] & $\begin{array}{l}\text { Explained link among Bundle Green HR and four dimensions of organizational performance which are } \\
\text { financial performance, operational performance, environmental performance and social performance in the } \\
\text { form of conceptual model }\end{array}$ \\
\hline
\end{tabular}




\begin{tabular}{|c|c|}
\hline Tang, Chen [28] & $\begin{array}{l}\text { The results reflected the six dimensions of Green HR: green recruitment and selection, green training and } \\
\text { development, green performance management, green pay and rewards and green involvement }\end{array}$ \\
\hline Ren, Tang [53] & $\begin{array}{l}\text { Puts light and draws immediate attentions towards the term Green HR and builds combined model composed } \\
\text { of contingencies, effects and antecedents of Green HR }\end{array}$ \\
\hline Sriram and Suba [54] & $\begin{array}{l}\text { The study revealed that execution of Green HRM depends on the employee commitments. Moreover, the study } \\
\text { also gave pros and cons of Green HRM on organizational attractiveness }\end{array}$ \\
\hline $\begin{array}{l}\text { Jabbour and de Sousa } \\
\text { Jabbour [55] }\end{array}$ & $\begin{array}{l}\text { The study merged two concepts green supply chain management and green human resource management and } \\
\text { provided evidence that teamwork, empowerment and culture work as a foundation of the both the concepts }\end{array}$ \\
\hline Renwick, Jabbour [7] & $\begin{array}{l}\text { The study revealed the nature of green human resource management at workplace. Moreover, it also linked } \\
\text { employee participation and green recruitment with environmental and financial performance in the light of } \\
\text { stakeholder theory }\end{array}$ \\
\hline Tariq, Jan [38] & $\begin{array}{l}\text { Strives to test potential mediating effect of green employee empowerment for executing green human resource } \\
\text { management practices }\end{array}$ \\
\hline Ahmad [56] & $\begin{array}{l}\text { Presented a simple meaning of the term green HR, concentrated on some of the Green HR practices and gave } \\
\text { future direction that how HR can contribute to organizations in terms of sustainability }\end{array}$ \\
\hline Milliman [57] & $\begin{array}{l}\text { The study revealed that in order to embrace sustainability, HR has to play unique role in promoting enviro- } \\
\text { friendly practices in organization }\end{array}$ \\
\hline Renwick, Redman [16] & $\begin{array}{l}\text { Based on AMO paradigm, the study revealed motivation among employees to perform green tasks revolves } \\
\text { around Green HRM }\end{array}$ \\
\hline Jackson, Renwick [5] & $\begin{array}{l}\text { Provided a comprehensive overview on several reflections of Green HRM which includes training and } \\
\text { development, performance management, compensation and rewards, learning capabilities and organizational } \\
\text { culture. }\end{array}$ \\
\hline Zoogah [37] & Worked on cognitive processing approach with respect to managers in the execution of Green HRM \\
\hline Jackson and Seo [58] & $\begin{array}{l}\text { Discussed real world issues by merging environmental sustainability and strategic human resource } \\
\text { management. }\end{array}$ \\
\hline Jabbour and Santos [14] & $\begin{array}{l}\text { The study proposed an integrated model by explain the dimensions of Green HRM like Green HR } \\
\text { participation, Green shortlisting, green training green performance appraisals, green compensation along with } \\
\text { management review, environmental policy, teamwork, organizational culture }\end{array}$ \\
\hline & RQ2: Applications/Execution of Green HRM \\
\hline $\begin{array}{l}\text { Khan and Noorizwan Muktar } \\
{[30]}\end{array}$ & $\begin{array}{l}\text { Gave empirical evidence on the perception of students in join green organizations through green recruitment } \\
\text { and provided justification that there are psychological thoughts that shape student's behavior to join } \\
\text { environment responsible firms }\end{array}$ \\
\hline Leidner, Baden [59] & The study revealed that there are contextual situations which impact the Green HRM practices \\
\hline Dubey and Gupta [60] & $\begin{array}{l}\text { The study exposed green training proved to be the most important application in executing environment } \\
\text { friendly practices in the corporations }\end{array}$ \\
\hline Jain and D'lima [61] & $\begin{array}{l}\text { The study elaborated how green HRM is perceived by the eye's generation Y, though application of green } \\
\text { hiring, green performance management, green rewards and recognitions }\end{array}$ \\
\hline Nobari, Seyedjavadin [62] & $\begin{array}{l}\text { Proposed } 12 \text { factors in implementing Green HRM practices and training, recruitment and rewards were } \\
\text { considered pioneers for executing green HRM practices }\end{array}$ \\
\hline Mishra [63] & $\begin{array}{l}\text { The study revealed the presence of Green HRM practices in Indian manufacturing sector but the applications } \\
\text { of these practices remain blur }\end{array}$ \\
\hline Guerci and Carollo [64] & $\begin{array}{l}\text { The study revealed } 8 \text { types of paradoxes professed by organizations and puts light on the green HRM practices } \\
\text { at organizational level }\end{array}$ \\
\hline Haddock-Millar, Sanyal [34] & $\begin{array}{l}\text { The study provides the cross-country comparison of three European counties by discussing environmental } \\
\text { management from the perspectives of peoples }\end{array}$ \\
\hline [65] & $\begin{array}{l}\text { the study emphasized to link HRM and sustainability and concluded that application of green HRM comes } \\
\text { with positive effects }\end{array}$ \\
\hline Mishra, Sarkar [33] & The study revealed the application of Green HRM practices to meet sustainable development goals in India \\
\hline Dias-Angelo, Jabbour [35] & $\begin{array}{l}\text { The study exposed that Environmental training needs to be incorporated in the hotel industry and the } \\
\text { connection between HRM and environmental objectives are not clear }\end{array}$ \\
\hline $\begin{array}{l}\text { Saturnino Neto, José } \\
\text { Chiappetta Jabbour [66] }\end{array}$ & $\begin{array}{l}\text { To develop low carbon products and to mitigate the harmful impact on climate change, environmental training } \\
\text { is imperative }\end{array}$ \\
\hline & RQ3: Factors of Green HRM \\
\hline Yu, Chavez [67] & ental cooperation with suppliers significantly impacts GHRM \\
\hline Obeidat, Al Bakri [41] & Environmental orientation along with the top management support determines Green HRM scholarship \\
\hline Singh, Giudice [68] & Green leadership and green innovation are the determinants of green human resource management \\
\hline Yong, Yusliza [39] & $\begin{array}{l}\text { The study exposed that green HRM scholarship is affected by both green relational and human capital, on the } \\
\text { other hand green structural capital do not define green HRM }\end{array}$ \\
\hline $\begin{array}{l}\text { Moraes Silvana } \text { de, } \\
\text { Chiappetta Jabbour Charbel } \\
{[42]}\end{array}$ & $\begin{array}{l}\text { The study revealed that Environmental knowledge works as a determinant of green practices and have positive } \\
\text { impact on environmental training }\end{array}$ \\
\hline Yusliza, Othman [69] & $\begin{array}{l}\text { Green employee empowerment significant determines Green HRM and the study exposed that GEE impacted } \\
\text { Green HRM scholarship }\end{array}$ \\
\hline Guerci, Longoni [48] & $\begin{array}{l}\text { The findings proposed that performance and stakeholder pressure both are mediated by green HRM } \\
\text { scholarship }\end{array}$ \\
\hline $\begin{array}{l}\text { Yong Jing and Mohd-Yusoff } \\
\text { [70] }\end{array}$ & $\begin{array}{l}\text { The change management and strategic approach has positive effect on green rewards, green analysis and job } \\
\text { description }\end{array}$ \\
\hline Sawang and Kivits [71] & The study revealed that top management green attitude impacts their decision to execute Green HRM practices \\
\hline Teixeira, Jabbour [43] & $\begin{array}{l}\text { The study exposed that top management commitment, teamwork and organizational culture along with } \\
\text { sustainable practices are the pioneer factors or determinants which provide a way for being more sustainable }\end{array}$ \\
\hline
\end{tabular}




\begin{tabular}{|c|c|}
\hline Rangarajan and Rahm [72] & $\begin{array}{l}\text { The study was conducted in US cities and it exposed that environmental awareness programs, education and } \\
\text { income level have effect on strategic HR practices }\end{array}$ \\
\hline \multicolumn{2}{|r|}{ RQ4: Effects of Green HRM } \\
\hline Hameed, Khan [29] & $\begin{array}{l}\text { the study exposed that green HRM practices are positively related to organizational citizenship behavior for } \\
\text { the environment and green employee empowerment mediated the relationship }\end{array}$ \\
\hline Yong, Yusliza [73] & $\begin{array}{l}\text { The study exposed that green training and green job analysis and recruitment positively affected the } \\
\text { sustainable performance but green performance and selection don't have effects on sustainability }\end{array}$ \\
\hline Obeidat, Al Bakri [41] & $\begin{array}{l}\text { the study revealed that green HRM has positive effect on environmental performance and Green HRM } \\
\text { mediated between top management commitment, international environmental orientation and environmental } \\
\text { performance }\end{array}$ \\
\hline Jerónimo, Henriques [74] & $\begin{array}{l}\text { The study exposed that organizational sustainability is positively affected by green HRM practices like green } \\
\text { recruitment and green training. However green compensation was irrelevant and had no impact on } \\
\text { organizational sustainability. }\end{array}$ \\
\hline Saeed, Afsar [46] & $\begin{array}{l}\text { the study revealed that environmental passion greatly impacts Green HRM and green HRM practices lead to } \\
\text { environmental performance }\end{array}$ \\
\hline Kim, Kim [45] & $\begin{array}{l}\text { The study was conducted in hotel industry and the results showed that both environmental-friendly attitude } \\
\text { and organizational commitment are affected by Green HRM. Moreover, the environmental performance of } \\
\text { hotels was also increased }\end{array}$ \\
\hline Roscoe, Subramanian [50] & $\begin{array}{l}\text { The study exposed that organizational green culture depends on leadership. Moreover, GHRM affected } \\
\text { environmental performance. }\end{array}$ \\
\hline Pham, Tučková [75] & $\begin{array}{l}\text { The results exposed that green training improve employee green behavior. Moreover, the interaction effect on } \\
\text { organizational citizenship behavior depend on training, employee involvement and performance management }\end{array}$ \\
\hline Chaudhary [44] & $\begin{array}{l}\text { The study performed sequential mediating of OA and OP on JPI. Findings revealed that Green HRM practices } \\
\text { positively impacts JPI with significant effect of serial mediation }\end{array}$ \\
\hline $\begin{array}{l}\text { Silva Marco Antonio Batista, } \\
\text { Costa Priscila Rezende [76] }\end{array}$ & $\begin{array}{l}\text { The study exposed that in order to improve environmental sustainability in the organizations and to meet } \\
\text { environmental goals, green/ environmental training is imperative }\end{array}$ \\
\hline Al Kerdawy [77] & $\begin{array}{l}\text { The study exposed that the interaction effect of CSEV positively related to the effect of Green HRM on CRS } \\
\text { in organizations and both green HRM and organizational support positively impacts CSR }\end{array}$ \\
\hline Chaudhary [78] & $\begin{array}{l}\text { The study was conducted from the perspective of students and environmental orientation was found to have } \\
\text { positive interaction effect with Green HRM and job pursuit intention. }\end{array}$ \\
\hline Shen, Dumont [47] & $\begin{array}{l}\text { Perceived Green HRM practices impacts employee performance in terms of task, organizational citizenship } \\
\text { behavior and intention to quit through mediating effect of organizational identification }\end{array}$ \\
\hline Luu [79] & $\begin{array}{l}\text { The study exposed that in order to have green performance recovery, employee training, employee } \\
\text { empowerment and rewarding systems for employees acts as a bridge and positive association was found } \\
\text { between these variables in which employee environmental commitment was tested as a mediator }\end{array}$ \\
\hline Zaid, Jaaron [51] & $\begin{array}{l}\text { Based on triple bottom line in conceptualizing sustainable performance, the study revealed that both green } \\
\text { HRM and green SCM positively affected sustainable performance }\end{array}$ \\
\hline $\begin{array}{l}\text { Bombiak and Marciniuk- } \\
\text { Kluska [80] }\end{array}$ & $\begin{array}{l}\text { The impact of Green HRM was found to have positive correlated with sustainable development goals of the } \\
\text { company }\end{array}$ \\
\hline $\begin{array}{l}\text { Aragão Claudia and Jabbour } \\
\text { Charbel Jose [81] }\end{array}$ & $\begin{array}{l}\text { Although Green/Environmental attained limited goals but green training was seen as a potential source of } \\
\text { improvement among organizations. }\end{array}$ \\
\hline Bangwal, Tiwari [82] & $\begin{array}{l}\text { Empirically tested the relationship between Green HRM and environmental performance and work life } \\
\text { balance significantly mediated the relationship }\end{array}$ \\
\hline Nejati, Rabiei [83] & $\begin{array}{l}\text { The study that all green HRM practices like green recruitment, green training and development, green } \\
\text { employee empowerment and green pay and rewards has positive impact on green supply chain management } \\
\text { and the interaction effect of resistance to change moderated the link between GHRM and GSCM }\end{array}$ \\
\hline Gholami, Rezaei [84] & $\begin{array}{l}\text { The study revealed a d measured the impact on Organizational performance and employee wellbeing by green } \\
\text { HRM practices and the impact was statically significant }\end{array}$ \\
\hline Guerci, Montanari [85] & $\begin{array}{l}\text { Findings exposed that green organizational reputation attracts potential employees and indicated that potential } \\
\text { job applicants prefer green recruitment practice }\end{array}$ \\
\hline O'Donohue and Torugsa [86] & $\begin{array}{l}\text { The study performed the interaction effect such that higher the level of green HRM practices higher will be } \\
\text { the economic benefits and Green HR positively interacted between financial performance and pro- } \\
\text { environmental management }\end{array}$ \\
\hline Pinzone, Guerci [8] & $\begin{array}{l}\text { The study measured the role of Green HRM practices on voluntary behavior and found that the result is } \\
\text { positive and statistically significant and environmental management partially mediated the relationship }\end{array}$ \\
\hline Zibarras and Coan [87] & $\begin{array}{l}\text { The study was conducted in UK organizations to measure the extent of pro-environmental HRM practices but } \\
\text { found limited implementation of pro-environmental HRM practices }\end{array}$ \\
\hline Paillé, Chen [40] & $\begin{array}{l}\text { The study indicated that environmental performance is enhanced by strategic HRM practices and } \\
\text { organizational citizenship behavior mediated the relationship. }\end{array}$ \\
\hline Jabbour [36] & $\begin{array}{l}\text { Environmental training was found to positively impact environmental management in brazil with ISO verified } \\
\text { corporations }\end{array}$ \\
\hline Wagner [88] & $\begin{array}{l}\text { The impact of environmental management system was positively related to employee recruitment, employee } \\
\text { benefits and workplace satisfaction. Moreover, the study found that higher the EMS implementation higher } \\
\text { will be the economic benefits }\end{array}$ \\
\hline Daily Bonnie [89] & $\begin{array}{l}\text { Both environmental training of employee and employee environmental empowerment was significantly } \\
\text { positively to environmental performance and managers complemented the role of such trainings }\end{array}$ \\
\hline $\begin{array}{l}\text { Carmona-Moreno, Céspedes- } \\
\text { Lorente [90] }\end{array}$ & $\begin{array}{l}\text { The study revealed that those corporations who execute environmental HR practices will have enhanced } \\
\text { organizational performance and better ways to implement cleaner production techniques }\end{array}$ \\
\hline
\end{tabular}




\section{DISCUSSION CONCLUSIONS CONTRIBUTIONS}

As debated earlier, that the paradigm of green HRM has got noteworthy attention among scholars and journals, this segment will put light on some of the important numerical facts relating to green human resource management from 2008 to 2020 .

The Figure 2 shows the numerical analysis of green HRM in terms of concentration. 17 percent articles of the total span of the articles represent the execution of green HRM practices as this is in line with the argument posted by Dias-Angelo, Jabbour [35] that green HRM practices need formal merging with traditional HRM practices in order to executed in a correct way. Similarly, 16 percent articles of the total domain of the article represents the factors of green HRM which is lowest among all concentrations. As far as the reflection segment is concerned which highlights 26 percent of the total span of the documents tells that still room for conceptualization of the Green HRM and more dimensions should be addressed. Finally, effects of green HRM which is 41 percent of the total span of the documents shows the attention and importance of Green HRM scholarship in terms of noteworthy gains at organizational level.

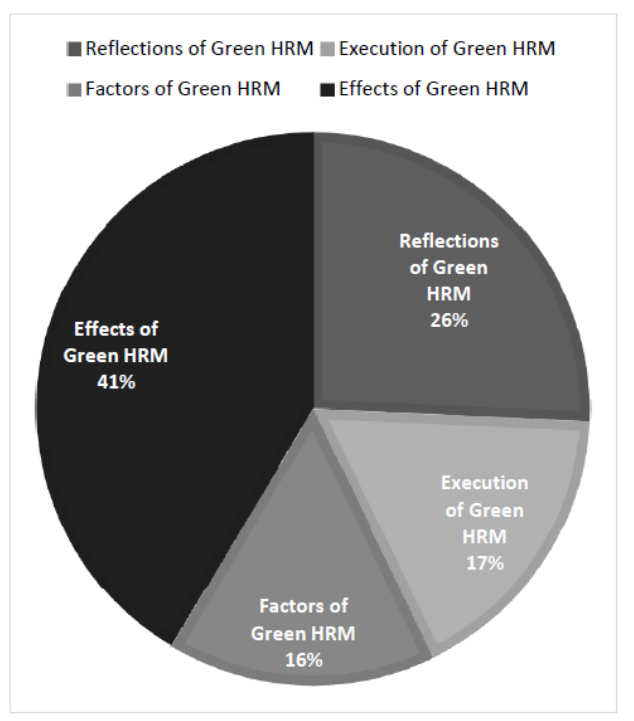

Figure 2. Divisions of green HRM paradigm

\subsection{Trajectory of green HRM paradigm}

The systematic review belongs to years from 2008 till 2020. The work of Renwick, Redman [23] was the initial year when this novel concept emerged. The trajectory in Figure 3 highlights that very few studies were performed during the initial year from 2008 to 2015 . However, the green HRM paradigm gained noteworthy consideration after 2015. A peak can be seen from the graph (black line) in which 2016, 2018, 2019 and now till 2020 that GHRM is still in developing phase. Moreover, this peak also highlights the concerns of environmental issues among scholars and now it is a wellestablished fact that this topic is famous among academia.

\subsection{Documents produced by countries}

The current systematic review split country wise contributions in GHRM Paradigm. Figure 4 shows that UK and USA are among the top leading countries in producing
Green HRM papers with 16 percent and 14 percent from the overall span of the papers respectively. Followed by Brazil 14 percent, India and Malaysia both 10 percent, Australia 8 percent, China 7 percent while France and Italy both produced 6 percent documents. Out of 100 percent 50 percent documents were produced by developed nations like UK, USA, France, Italy, Australia. On the other hand, developing states like China, India, Brazil and Malaysia produced 41 percent of the total span of the documents. These results are matched with the global trend of studies in the field of management in which the prominent societies are American and Europe followed by emerging Asian societies [91]. Moreover studies in develop nations made a cross cultural comparison for instant, Haddock-Millar, Sanyal [34] merge three countries UK, Germany and Sweden to judge the execution of green HRM practices. As far as the developing nations are concerned majority of the studies were conducted on the effects of green HRM at employee and firm level [30, 41, 45, 50, 75]. In short, this variety of distribution to study Green HRM from different perspectives shows the importance of this concept as well as their concern towards to growing environmental issues.

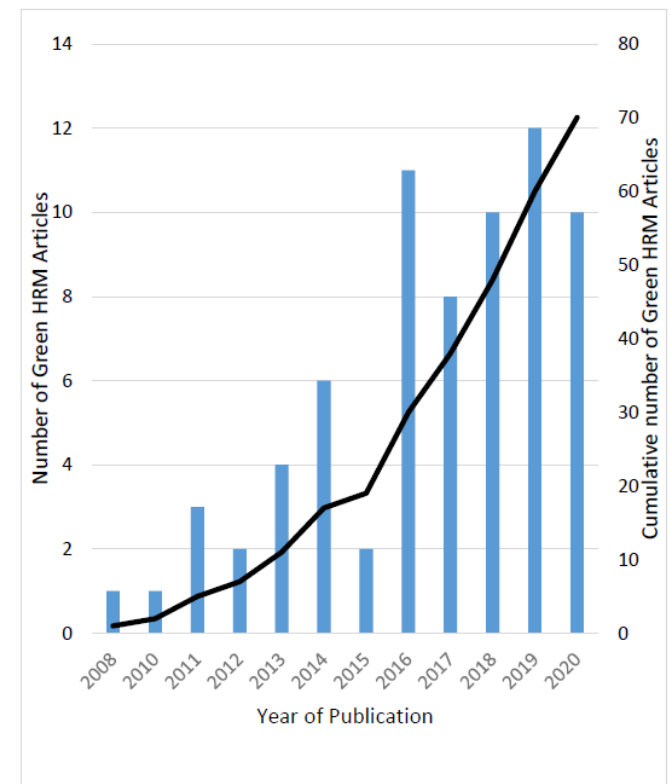

Figure 3. Number of papers published by Year

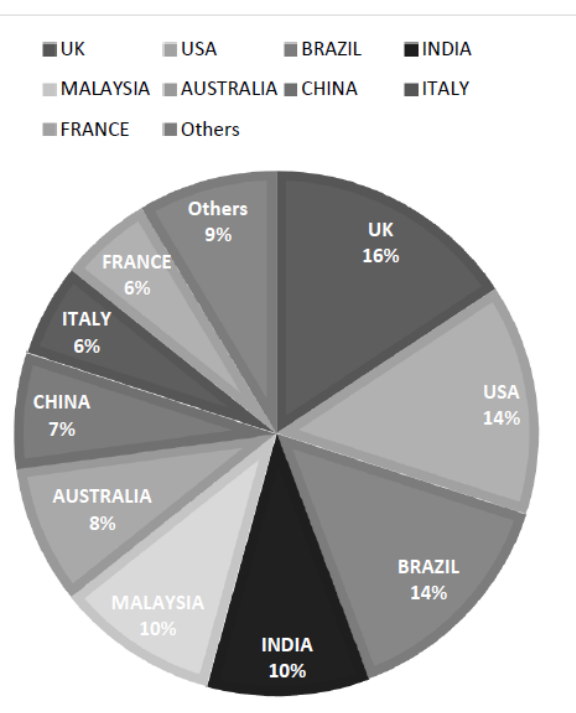

Figure 4. Division of countries produced Green HRM papers 


\subsection{Green HRM paradigm in terms of Underpinning Theories}

To develop theoretical relationships among variables, theories are need and the paradigm of Green HRM also revolves around the many theories. Theories that were used in this novel concept are RBV (Resource Based View) theory, SIT (Social Identity theory), stakeholder theory, SET (social exchange theory), paradox theory, intellectual capital-based view theory, signaling theory, AMO (ability, motivation, opportunity) theory, TPB (theory of planned behavior), supplies- values fit theory, attribution theory, spill-over theory. As far as the division of theories is concerned majority of the studies based their theoretical foundations on RBV paradigm. For instance, studies which were executed on the effects of green HRM, the mainstream theory in most of the studies was RBV that was linking variables to get performance outcomes like environmental performance, social performance, financial performance. Moreover, the Green HRM paradigm is also dominated by SIT theory. This theory was mostly used from the perspectives of students who would be willing to join green firms like [30, 44, 78] as well as from the perceptions of employees like Kim, Kim [45] used this theory to check the perceptions of employees for their green behavior, Shen, Dumont [47] tested this theory to check the perceptions of employees for organizational citizenship behavior and intention to quit. Moreover, other theory at firm level $[48,88]$ used stakeholder theory. Other theories that were used are [44, 85] tested signaling theory, Sawang and Kivits [71] used theory of planned behavior to judge top management attitude towards being environmental responsible, AMO theory by [42, 67], Luu [79] used attribution theory and O'Donohue and Torugsa [86] used absorptive capacity theory.

\subsection{Division of methods}

This section highlights the major methodologies used in green HRM paradigm, namely quantitative studies, qualitative studies, conceptual studies and mix method studies. Figure 5 shows that the most prominent type of approach used in green HR was quantitative paradigm which represents 52 percent of the total span of the documents. Most of these studies used primary data as their source, followed by conceptual studies which indicates 24 percent of the total span of the documents. The least used methodologies were qualitative and mixed approach representing 17 percent and 7 percent respectively. The possible reason could be due to the fact that qualitative studies and mix method studies need more time, resources and technical skills.

\subsection{Documents produced by journals}

The documents on Green HRM paradigm were published by several journals, however Journal of Cleaner Production and International Journal of Human Resource Management takes the lead in producing 8 articles, followed by Business Strategy and Environment 3 while Asia Pacific Journal of Human Resource, Corporate Social Responsibility and Environmental Management and German Journal of Human Resource Management produced 2 documents each. On the other hand, journals with less than 2 documents were inserted in others category. Based on documents produced by journals, it shows the versatile domain of Green HRM paradigm. Figure 6 shows the prominent journals.

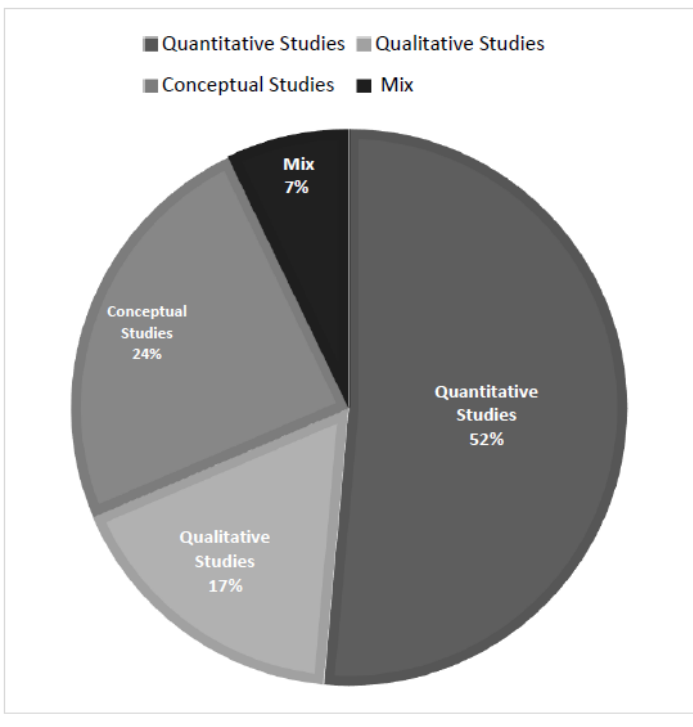

Figure 5. Methodological division

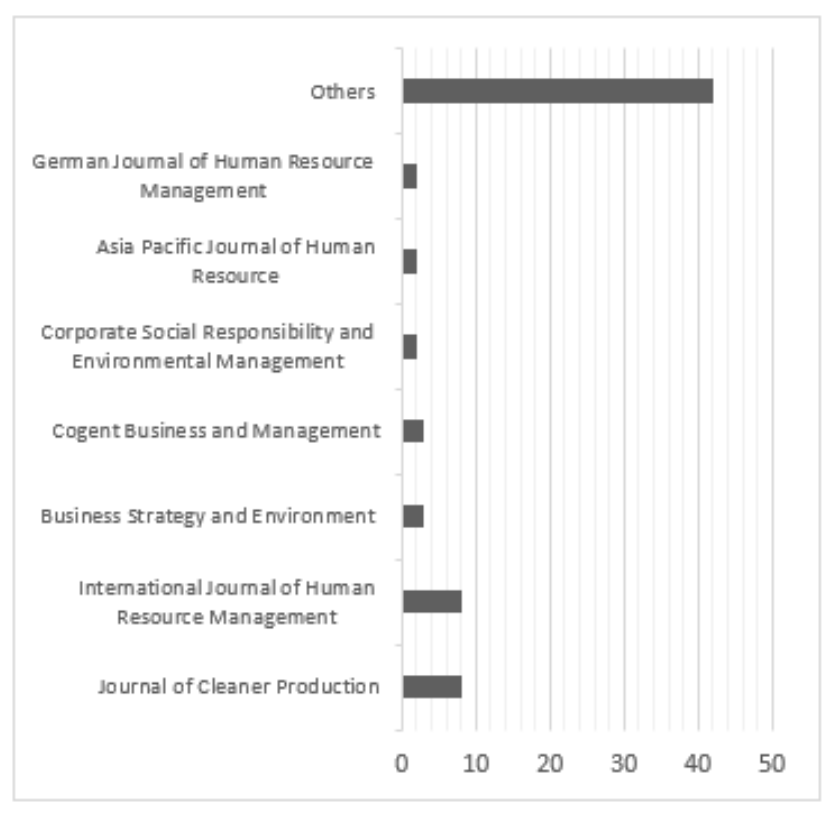

Figure 6. Prominent journals

This systematic review from 2008 to 2020 provides a comprehensive understanding of Green HRM paradigm. It shows the prominence of Green HRM as a pathway towards sustainable development and to gain competitive edge in the current world scenario. This review adopted an impartial approach for the collection of articles. To ensure quality work, data collected from one the most reliable and prominent database Scopus containing well reputed and impact factor journals. Secondly, we divided the paradigm of green HRM into four main segments as a new way of understanding this concept. Thirdly, the available information on Green HRM from these well reputed journals provided a collaborative approach in understating the definition of this novel concept.

The peak from 2016 till now presents a holistic view of green HRM paradigm this is due to the fact that organizations are now viewing it as a source of competitive edge. Moreover, this also highlights that peak is also due to the "World Economic Forum 2015" conference which emphasized on the concept circular economies and attaining sustainable development goals. 
With regard to RQ1, different scholars see the paradigm of green HRM from different lenses and provided various dimensions of this novel concept hence it will help future researchers to fully understand the various reflection of Green HRM. Moreover RQ2, on the execution applications of green HRM, the scholars acknowledged that the rank of green training is superior among all other applications of green HRM. In addition, to compete in the global world economy, the firms need proper execution of green HRM practices to embellish sustainable organizational performance and this is in line with $[16,17]$. Besides this, directors, managers, supervisees must work in collaboration to apply cleaner production techniques by reducing waste at its source rather than treating it later and all this can be accomplished by execution of green HRM practices and this argument was also proposed by [18].

The third section which provided insights with regard to the factors of green HRM, the scholars agreed that teamwork, organizational culture, giving employees voices to speak about environmental issues allows firm to become sustainable. A well competent leadership and management commitment for the environmental among executives can perform human resource engineering by motivating them to engage in green tasks and solving environmental issues arise in the organizations

The forth section which elaborated the effects of Green HRM, showed the potential benefits in terms of performance outcomes for organizations. In addition, firms can work in coordination with government agencies to reduce the harmful effects caused by the organizational operations on the nearby society. For instance, developing eco- industrial parks to reduce air pollution, reducing waste through sustainable processes during production, onsite recycling like residual of one industry can be used as raw material for the other industry etc.

In addition, the numerical analysis of green HRM paradigm, provided interesting trends, like developed counties, the developing countries are also now showing its concerns towards sustainable issues this is because emerging countries focus more on manufacturing processes and human interaction with the environment can possibly harm ecological systems. This argument was also supported by [17].

This study also contributed towards the underpinning theories on green HRM literature. This paper discussed almost all the theories and this will help future researchers to frame their theocratical models. Another contribution of this study was to identify the productive journals in green HRM paradigm, this will help future researchers to easily locate journals as potential places of publishing their work. Moreover, least used method was the mixed approach as only 7 percent articles followed this approach.

Through this systematic review, future gaps in green HRM paradigm are also enlightened. Firstly, the study will provide the future research opportunities based on the above analysis and secondly this study will explain thoroughly some more future endeavors in green HRM paradigm.

Based on the numerical analysis which shows that only 16 percent studies were conducted on the factors of green HRM paradigm, future studies should look for more factors to address green HRM. For instance, what is the role of green transformation leadership in gaining environmental excellence, moreover majority of the studies used top management and green employee empowerment as the antecedents of green HRM paradigm but none of the studies measured the intervening effect of these variables in gaining environmental excellence therefore future studies might look for these interventions.

In addition, most of the studies were conducted on the effects of green HR paradigm and no doubt gaining competitive edge is very important but none of the studies provided the working process of green HRM paradigm in gaining competitive advantage. Although scholars acknowledged working process of green training but future studies should look for green communication channels as a mediating mechanism for green HRM and competitive advantage because communication is power of this century. Flow of green communication from upper level management to the bottom level will help in maintaining a green organizational culture in the organizations.

As far as the underpinning theories in green HRM paradigm is concerned, RBV theory was mostly used at firm level and social identity at employee level, however theory of planned behavior was the least used and future studies should use this theory at employee level. Moreover, future studies can also integrate theories like AMO, SET, SIT in one setting i.e. one model for quantitative studies. The will give future researchers to predict how green HRM paradigm impacts behaviors at employee level and performance at firm level.

Future work in the field of green HRM, should look for cross cultural comparison, like developing country comparison with the developing country instead of developed country. This will help in gaining more insights about original implementation of the green HRM paradigm in developing countries and help scholars to identify cross cultural contradictions.

Moreover, the authors noted the methodological gap. There is an immense need to apply mix methodology in green HRM literature like explanatory sequential research design, exploratory sequential research design [92]. Although time, resources and skills are required in mixed paradigm but it will provide more details towards this novel concept as still it's in developing phase.

\section{HOW REFLECTIONS, APPLICATIONS, FACTORS AND EFFECTS OF GREEN HRM LEAD TO SUSTAINABLE DEVELOPMENT}

From the above analysis on green HRM, we developed the framework that reveals how green HRM lead towards sustainable development. Specifically, this framework draws attention towards those variables which can contribute to achieve sustainable development at organizational and employee level. This framework serves as a guide to modern researchers to execute empirical studies to test antecedents, mediators and moderators by utilizing different theories to understand green HRM more deeply to meet sustainable development goals. Based on the [93], the sustainable development revolves around three main spectrums, the social, environmental and economic concerns, strives for the development that meets the of the people and for future generations and the need for all sections of life to get involved in achieving sustainability, therefore it is not limited to the environmentalists in any organization but it needs feedback from the HR executives as well. As discussed by [5, 30, 33] that HRM has a great potential if merged with sustainability.

Organizations can have win-win situation if the leaderships attitude towards sustainable issues is positive. They can make environmental strategies, technological advancements in the 
organizations, promotion green culture among employees to shape them towards sustainability issues. Moreover, the green HRM has the potential to merge sustainable development goals with the hiring process, selecting talent magnets who show motivation towards sustainability, green training of people in relation to sustainable development, communication new employees' information about sustainable development issues, amalgamating environmental and social concerns in performance appraisals, giving green incentives to employees based on green performance appraisals, giving power to employee to perform green tasks and allowing them in decision making regarding environmental issues. Therefore, by incorporating green HRM and sustainable development together organizations can have improved environmental performance like reduction in wastes produced during production processes, better environmental image, improved social performance of employees like job satisfaction, less turnover and improved economic performance like growth in profits. In short, the integrative approach of all levels of green HRM can lead to sustainable development.

Proposition A: The Integration of factors, reflections, applications and effects of green human resource management supports sustainable development.

Proposition B: The persons who are in the decision making for employees' recruitment, selection, training and development should play a role for sustainable development.

Proposition C: The sustainability performance of organization is contingent upon employee's commitment towards sustainable development.

Proposition D: Potential mediating mechanisms like top management commitment, green employee empowerment, green employee involvement can support organizations to meet sustainable performance like environmental performance, social performance and economic performance.

Proposition E: Change management and training capacity of the firms have to be a moderator in order to improve sustainable performance of the organization.

Proposition F: Organizations with high sustainable performance can have high organizational reputation for sustainability development.

Proposition G: Organizations with high sustainable performance can further attract potential talent which further helps to support sustainable development.

Proposition H: Sustainable Corporations incorporating green human resource management practices begin to draw attention of various investors that can provide support for sustainable development.

The Figure 7 shows the path to attain sustainable performance.

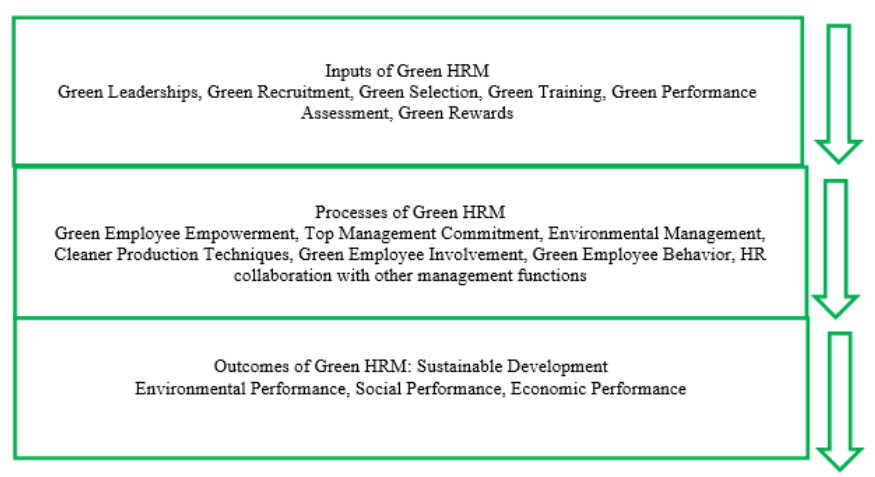

Figure 7. Path way towards sustainable performance

Underpinning Theories: RBV (Resource Based View) theory, SIT (Social Identity theory), stakeholder

theory, SET (social exchange theory), paradox theory, intellectual capital-based view theory, signaling theory, AMO (ability, motivation, opportunity) theory, TPB (theory of planned behavior), supplies- values fit theory, attribution theory, spill-over theory

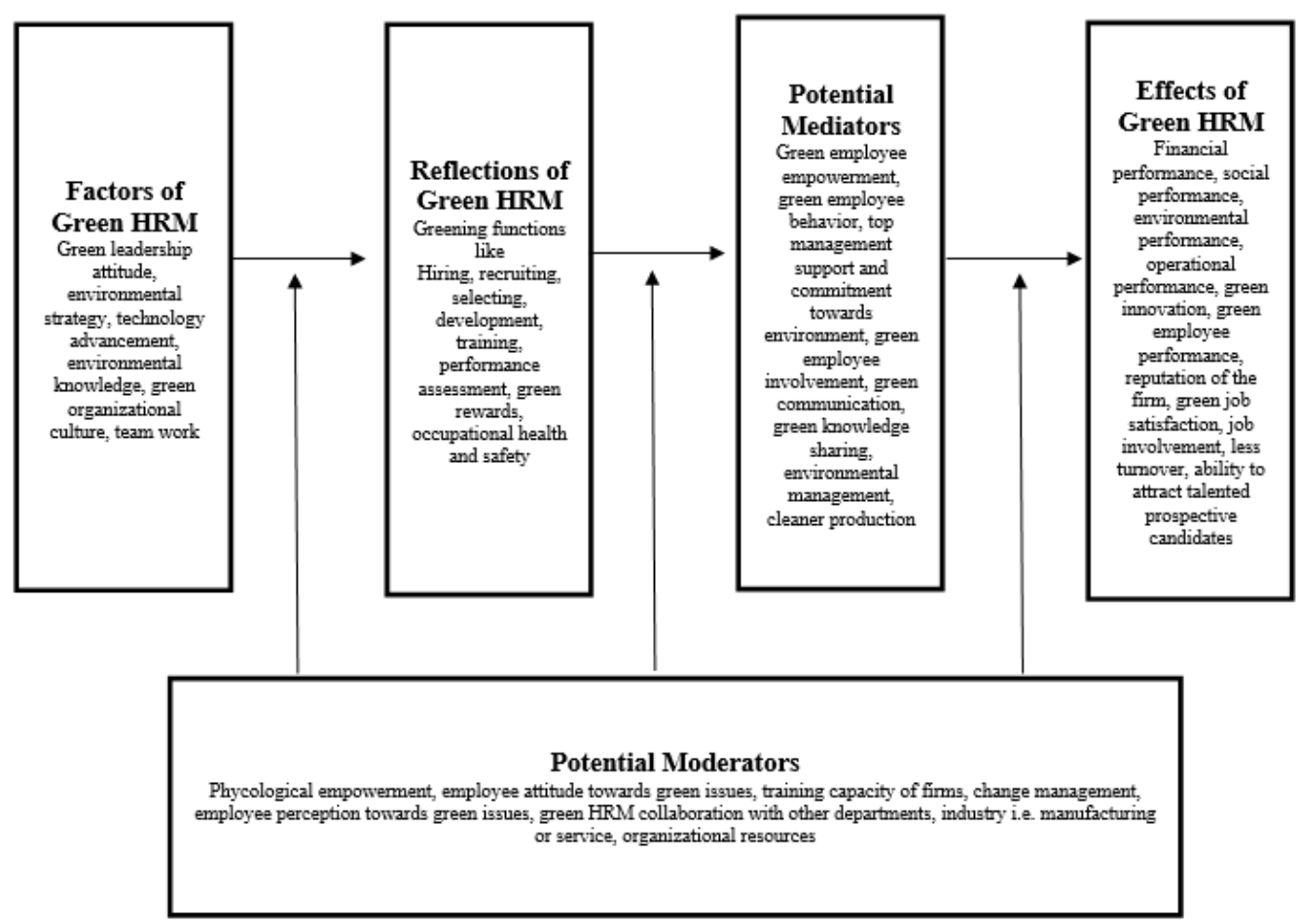

Figure 8. Green HRM theoretical framework for sustainable development 


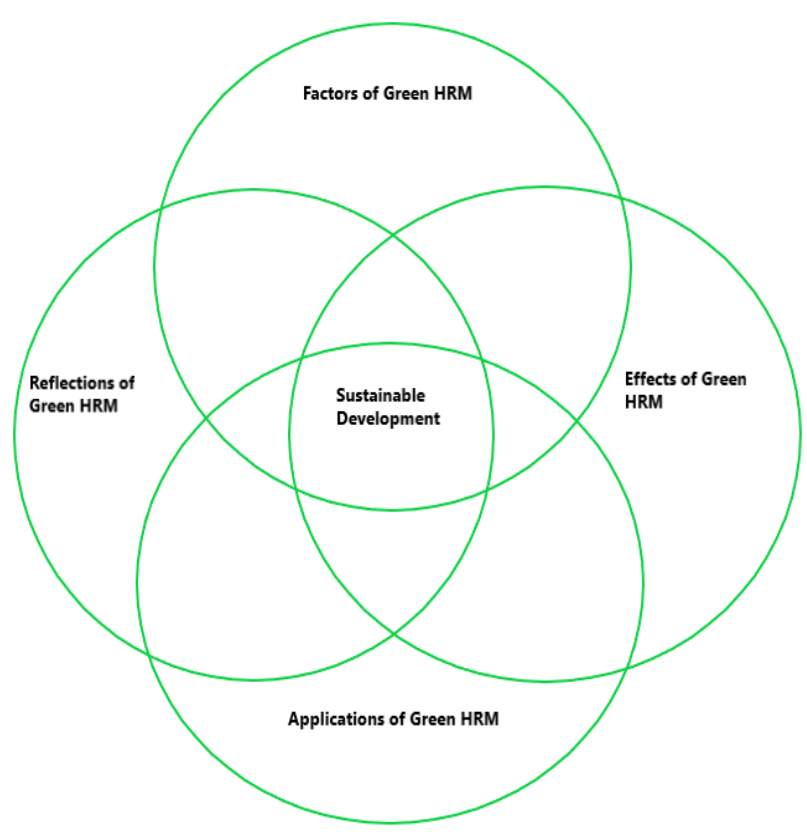

Figure 9. Integrating green HRM with sustainable development

Our review has provided a practical approach of merging sustainable development with green HRM scholarship. Firstly, the theoretical framework according to Figure 8 in order to have win- win situation, firms should strive for initiating environmental management programs and give voice to employees to check their perceptions regarding green HRM scholarship in order to meet sustainable development goals. Inter organizational surveys can better help in getting the feedback of the employees. Moreover, green communication channels and green banners in the organizations will also provide employee insights regarding green HRM. Secondly, organizations can use objective measures to encourage employees like green employee empowerment, top management support. Thirdly, the Figure 9 shows that, to completely embrace green HRM, merge all the sections of green HRM, this will help policy makers to identify potential factors, potential practices (Green HRM), potential intervening mechanisms(mediators), potential interaction mechanisms (moderators) to gain potential sustainability performance outcomes both at firm and employee levels to meet sustainable development goals.

\section{FINAL REMARKS}

This review has given scholarly investigation on green HRM scholarship by advancing previous works of [16-18]. The first question regarding reflections/dimensions provided an overview and draws attentions towards developing more instruments that are reliable and valid cross culture to investigate what other dimensions can be a part of green HRM, second question was to investigate reliable applications of green HRM, due to developing nature of this field, new applications should be addressed with the help of theories, thirdly factors of green HRM, we proposed various factors in our framework that help in executing green HRM, Fourthly we provided an integrative approach of all level of green HRM to ensure sustainable development Lastly, we provided potential mediators and moderators to further investigate their effects on organizations and employees in order to get more insights on the effects of green HRM. Finally, no doubt there is still room in this novel paradigm to ensure sustainable development and it cannot be overlooked. Although we tried to give a holistic view on green HRM scholarship, yet this systematic review is lying on the studies conducted in Scopus database from year 2008 to 2020, therefore, studies conducted outside could be a limitation. Secondly, we looked for those journals that are high in quality but we know that other relevant works that were published in other journals therefore this study is not all inclusive. Moreover, this study also did not include the scales and the measurement items and single practices of green HRM, this was the reason of reducing more studies from the overall studies.

\section{ACKNOWLEDGMENT}

The authors wish to thank Azman Hashim International Business School Universiti Teknologi Malaysia for their Support and Cooperation.

\section{REFERENCES}

[1] Delmas, M., Blass, V.D. (2010). Measuring corporate environmental performance: The trade-offs of sustainability ratings. Business Strategy and the Environment, 19(4): 245-260. https://doi.org/10.1002/bse.676

[2] Sayyadi Tooranloo, H., Azadi, M.H., Sayyahpoor, A. (2017). Analyzing factors affecting implementation success of sustainable human resource management (SHRM) using a hybrid approach of FAHP and Type-2 fuzzy DEMATEL. Journal of Cleaner Production, 162: $1252-1265$

https://doi.org/10.1016/j.jclepro.2017.06.109

[3] Gupta, R.S.N. (2015). Green HRM: An innovative approach to environmental sustainability. In Twelfth AIMS International Conference on Management, India, pp. 825-830.

[4] Jabbour, C.J.C., Jabbour, A.B.L., Teixeira, A.A., Freitas, W.R.S. (2012). Environmental development in Brazilian companies: The role of human resource management. Environmental Development, 3: 137-147. https://doi.org/10.1016/j.envdev.2012.05.004

[5] Jackson, S.E., Douglas W. S. Renwick, Charbel J. C. Jabbour. (2011). State-of-the-art and future directions for green human resource management: Introduction to the special issue. German Journal of Human Resource Management, 25(2): 99-116. https://doi.org/10.1177/239700221102500203

[6] Freitas, W.R.d.S., Jabbour, C.J.C., Mangili, L.L. (2012). Building sustainable values in organizations with the support of human resource management: Evidence from one firm considered as the 'best place to work' in Brazil. Journal of Human Values, 18(2): 147-159. https://doi.org/10.1177/0971685812454483

[7] Renwick, D.W., Jabbour, C.J.C., Muller-Camen, M., Redman, T., Wilkinson, A. (2016). Contemporary developments in Green (environmental) HRM scholarship. The International Journal of Human Resource Management, 27(2): 114-128. https://doi.org/10.1080/09585192.2015.1105844

[8] Pinzone, M., Guerci, M., Lettieri, E., Redman, T. (2016). 
Progressing in the change journey towards sustainability in healthcare: The role of 'Green' HRM. Journal of Cleaner Production, 122: 201-211. https://doi.org/10.1016/j.jclepro.2016.02.031

[9] Guerci, M., Longoni, A., Luzzini, D. (2015). Translating stakeholder pressures into environmental performance the mediating role of green HRM practices. The International Journal of Human Resource Management, 27(2):

https://doi.org/10.1080/09585192.2015.1065431

[10] Longoni, A., Luzzini, D., Guerci, M. (2018). Deploying environmental management across functions: the relationship between green human resource management and green supply chain management. Journal of Business Ethics, 151(4): 1081-1095. https://doi.org/10.1007/s10551-016-3228-1

[11] Jabbour, C.J.C., Renwick, D.W.S. (2018). The soft side of environmentally-sustainable organizations. RAUSP Management Journal, 53(4). https://doi.org/10.1108/RAUSP-07-2018-0044

[12] Ahmad, S. (2015). Green human resource management: policies and practices. Cogent Business \& Management, 2(1):

$1-13$. https://doi.org/10.1080/23311975.2015.1030817

[13] Mishra, D.K., Rani, S. (2014). Green HRM: Practices and Strategic Implementation in the Organizations. International Journal on Recent and Innovation Trends in Computing and Communication, 2(11): 3633-3639. https://doi.org/10.1504/WRSTSD.2014.062374

[14] Jabbour, C.J.C., Santos, F.C.A. (2008). Relationships between human resource dimensions and environmental management in companies: proposal of a model. Journal of Cleaner Production, 16(1): 51-58. https://doi.org/10.1016/j.jclepro.2006.07.025

[15] Cohen, E., Taylor, S., Muller-Camen, M. (2012). HRM's role in corporate social and environmental sustainability. SHRM Report, 1: 1-16.

[16] Renwick, D.W., Redman, T., Maguire, S. (2013). Green human resource management: A review and research agenda. International Journal of Management Reviews, 15(1): $\quad 1-14 . \quad$ https://doi.org/10.1111/j.14682370.2011.00328.x

[17] Khan, M.H., Muktar, S.N. (2020). A bibliometric analysis of green human resource management based on Scopus platform. Cogent Business \& Management, 7(1). https://doi.org/10.1080/23311975.2020.1831165

[18] Macke, J., Genari, D. (2019). Systematic literature review on sustainable human resource management. Journal of Cleaner Production, 208: 806-815. https://doi.org/10.1016/j.jclepro.2018.10.091

[19] Tranfield, D., Denyer, D., Smart, P. (2003). Towards a methodology for developing evidence-informed management knowledge by means of systematic review. British Journal of Management, 14(3): 207-222. https://doi/abs/10.1111/1467-8551.00375

[20] Hohenstein, N.O., Feisel, E., Hartmann, E. (2014). Human resource management issues in supply chain management research: A systematic literature review from 1998 to 2014. International Journal of Physical Distribution \& Logistics Management, 44(6): 434-463. https://doi.org/10.1108/IJPDLM-06-2013-0175

[21] Rashman, L., Withers, E., Hartley, J. (2009). Organizational learning and knowledge in public service organizations: A systematic review of the literature.
International Journal of Management Reviews, 11(4): 463-494. 2370.2009.00257.x

https://doi/abs/10.1111/j.1468-

[22] Moher, D., Liberati, A., Tetzlaff, J., Altman, D.G., The PRISMA Group. (2010). Preferred reporting items for systematic reviews and meta-analyses: The PRISMA statement. International Journal of Surgery, 8(5): 336341. https://doi.org/10.1016/j.ijsu.2010.02.007

[23] Renwick, D., Redman, T., Maguire, S. (2008). Green HRM: A review, process model, and research agenda. University of Sheffield Management School Discussion Paper, 1: 1-46.

[24] Scopus Data. 2019. https://www.elsevier.com/ data/assets/pdf_file/0017/1

14533/Scopus_GlobalResearch_Factsheet2019_FINAL _WEB.pdf.

[25] Siyambalapitiya, J., Zhang, X., Liu, X. (2018). Green human resource management: A proposed model in the context of Sri Lanka's tourism industry. Journal of Cleaner Production, 201: 542-555. https://doi.org/10.1016/j.jclepro.2018.07.305

[26] Shah, M. (2019). Green human resource management: Development of a valid measurement scale. Business Strategy and the Environment, 28(5): 771-785. https://doi.org/10.1002/bse.2279

[27] Mousa, S.K., Othman, M. (2020). The impact of green human resource management practices on sustainable performance in healthcare organisations: A conceptual framework. Journal of Cleaner Production, 243: 118595. https://doi.org/10.1016/j.jclepro.2019.118595

[28] Tang, G., Chen, Y., Jiang, Y., Paillé, P., Jia, J. (2017). Green human resource management practices: scale development and validity. Asia Pacific Journal of Human Resources, 56(1): 31-55. https://doi.org/10.1111/17447941.12147

[29] Hameed, Z., Khan, I.U., Islam, T., Sheikh, Z., Naeem, R.M. (2017). Do green HRM practices influence employees' environmental performance? International Journal of Manpower, 41(7): 1061-1071. https://doi.org/10.1108/IJM-08-2019-0407

[30] Khan, M.H., Muktar, S.N. (2020). Mediating role of organizational attractiveness on the relationship between green recruitment and job pursuit intention among students of Universiti Teknologi Malaysia. Cogent Business \& Management, 7(1). http://doi.org/10.1080/23311975.2020.1832811

[31] Mukherjee, B., Chandra, B. (2018). Conceptualizing green human resource management in predicting employees' green intention and behaviour: A conceptual framework. Prabandhan: Indian Journal of Management, 11(7): http://doi.org/10.17010/pijom/2018/v11i7/129940

[32] Keeble, B.R. (1988). The Brundtland report: 'Our common future'. Medicine and War, 4(1): 17-25. https://doi.org/10.1080/07488008808408783

[33] Mishra, R., Sarkar, S., Kiranmai, J. (2014). Green HRM: innovative approach in Indian public enterprises. World Review of Science, Technology and Sustainable Development, 11(1): 26-42. https://doi.org/10.1504/WRSTSD.2014.062374

[34] Haddock-Millar, J., Sanyal, C., Müller -Camen, M. (2016). Green human resource management: A comparative qualitative case study of a United States multinational corporation. The International Journal of 
Human Resource Management, 27(2): 192-211. https://doi.org/10.1080/09585192.2015.1052087

[35] Dias-Angelo, F., Jabbour, C.J.C., Calderaro, J.A. (2014). Greening the work force in Brazilian hotels: The role of environmental training. Work, 49(3): 347-356. https://doi.org/10.3233/WOR-141873

[36] Jabbour, C.J.C. (2013). Environmental training in organisations: From a literature review to a framework for future research. Resources, Conservation and Recycling, 74: 144-155. https://doi.org/10.1016/j.resconrec.2012.12.017

[37] Zoogah, D.B. (2011). The dynamics of green HRM behaviors: A cognitive social information processing approach. German Journal of Human Resource Management, 25(2): https://doi.org/10.2307/23279429

117-139.

[38] Tariq, S., Jan, F.A., Ahmad, M.S. (2016). Green employee empowerment: a systematic literature review on state-of- art in green human resource management. Quality \& Quantity, 50(1): 237-269. https://doi.org/10.1007/s11135-014-0146-0

[39] Yong, J.Y., Yusliza, M.Y., Ramayah, T., Fawehinmi, O. (2019). Nexus between green intellectual capital and green human resource management. Journal of Cleaner Production, $215:$ 364-374. https://doi.org/10.1016/j.jclepro.2018.12.306

[40] Paillé, P., Chen, Y., Boiral, O., Jin, J.F. (2014). The impact of human resource management on environmental performance: An employee-level study. Journal of Business Ethics, 121(3): 451-466. https://doi.org/10.1007/s10551-013-1732-0

[41] Obeidat, S.M., Al Bakri, A.A., Elbanna, S. (2020). Leveraging "Green" human resource practices to enable environmental and organizational performance: Evidence from the Qatari oil and gas industry. Journal of Business $\quad$ Ethics, 164(2): 371-388. https://doi.org/10.1007/s10551-018-4075-z

[42] Moraes Silvana de, S., Jabbour, C.J.C., Battistelle, R.A.G., Rodrigues, J.M., Renwick, D.S.W., Foropon, C., Roubaud, D. (2019). When knowledge management matters: interplay between green human resources and eco-efficiency in the financial service industry. Journal of Knowledge Management, 23(9): 1691-1707. https://doi.org/10.1108/JKM-07-2018-0414

[43] Teixeira, A.A., Jabbour, C.J.C., Jabbour, A.B.L.d.S. (2012). Relationship between green management and environmental training in companies located in Brazil: A theoretical framework and case studies. International Journal of Production Economics, 140(1): 318-329. https://doi.org/10.1016/j.ijpe.2012.01.009

[44] Chaudhary, R. (2019). Green human resource management and job pursuit intention: Examining the underlying processes. Corporate Social Responsibility and Environmental Management, 26(4): 929-937. https://doi.org/10.1002/csr.1732

[45] Kim, Y.J., Kim, W.G., Choi, H.M., Phetvaroon, K. (2019). The effect of green human resource management on hotel employees' eco-friendly behavior and environmental performance. International Journal of Hospitality Management, 76(Part A): 83-93. https://doi.org/10.1016/j.ijhm.2018.04.007

[46] Saeed, B.B., Afsar, B., Hafeez, S., Khan, I., Tahir, M., Afridi, M.A. (2018). Promoting employee's proenvironmental behavior through green human resource management practices. Corporate Social Responsibility and Environmental Management, 26(2): 424-438. https://doi.org/10.1002/csr.1694

[47] Shen, J., Dumont, J., Deng, X. (2018). Employees' perceptions of green HRM and non-green employee work outcomes: The social identity and stakeholder perspectives. Group \& Organization Management, 43(4): 594-622. https://doi.org/10.1177/1059601116664610

[48] Guerci, M., Longoni, A., Luzzini, D. (2016). Translating stakeholder pressures into environmental performance the mediating role of green HRM practices. The International Journal of Human Resource Management, 27(2):

https://doi.org/10.1080/09585192.2015.1065431

[49] Masri, H.A., Jaaron, A.A.M. (2017). Assessing green human resources management practices in Palestinian manufacturing context: An empirical study. Journal of Cleaner Production, 143: 474-489. https://doi.org/10.1016/j.jclepro.2016.12.087

[50] Roscoe, S., Subramanian, N., Jabbour, C.J.C., Chong, T. (2019). Green human resource management and the enablers of green organisational culture: Enhancing a firm's environmental performance for sustainable development. Business Strategy and the Environment, 28(5): 737-749. https://doi.org/10.1002/bse.2277

[51] Zaid, A.A., Jaaron, A.A.M., Talib Bon, A. (2018). The impact of green human resource management and green supply chain management practices on sustainable performance: An empirical study. Journal of Cleaner Production, 204: 965-979. https://doi.org/10.1016/j.jclepro.2018.09.062

[52] Khan, M.H. and S.N. Muktar, A bibliometric analysis of green human resource management based on scopus platform. Cogent Business \& Management, 2020. 7(1): p. 1831165. https://doi/abs/10.1080/23311975.2020.1831165

[53] Ren, S., Tang, G., Jackson, S.E. (2017). Green human resource management research in emergence: A review and future directions. Asia Pacific Journal of Management, $35(3)$ : 769-803. https://doi.org/10.1007/s10490-017-9532-1

[54] Sriram, D.V.P., Suba, M. (2017). Impact of green human resource management (G-HRM) practices over organization effectiveness. Jour of Adv Research in Dynamical \& Control Systems, 386-394. https://www.jardcs.org/backissues/abstract.php?archivei $\mathrm{d}=1118$.

[55] Jabbour, C.J.C., de Sousa Jabbour, A.B.L. (2016). Green Human Resource Management and Green Supply Chain Management: Linking two emerging agendas. Journal of Cleaner Production, 112: 1824-1833. https://doi.org/10.1016/j.jclepro.2015.01.052

[56] Ahmad, S. (2015). Green Human Resource Management: Policies and practices. Cogent Business \& Management, 2(1). https://doi.org/10.1080/23311975.2015.1030817

[57] Milliman, J. (2013). Leading-edge green human resource practices: Vital components to advancing environmental sustainability. Environmental Quality Management, 23(2): 31-45. https://doi/abs/10.1002/tqem.21358

[58] Jackson, S.E., Seo, J. (2010). The greening of strategic HRM scholarship. Organization Management Journal, 7(4): 278-290. https://doi.org/10.1057/omj.2010.37

[59] Leidner, S., Baden, D., Ashleigh, M.J. (2019). Green (environmental) HRM: Aligning ideals with appropriate 
practices. Personnel Review, 48(5): 1169-1185. https://doi.org/10.1108/PR-12-2017-0382

[60] Dubey, S., Gupta, B. (2018). Linking green HRM practices with organizational practices for organizational and environmental sustainability. International Journal of Engineering and Management Research (IJEMR), $8(2)$ :

$149-153$ https://doi.org/10.31033/ijemr.v8i02.11603

[61] Jain, N., D'lima, C. (2018). Green HRM-a study on the perception of Generation $\mathrm{Y}$ as prospective internal customers. International Journal of Business Excellence, 15(2):

199-208 https://doi.org/10.1504/IJBEX.2018.091916

[62] Nobari, A.R., Seyedjavadin, S.R., Arbatani, T.R., Roodposhti, F.R. (2018). Environmental concerns and green human resource management: A meta-synthesis. Iranian Journal of Plant Physiology, 8(4): 2573-2576.

[63] Mishra, P. (2017). Green human resource management. International Journal of Organizational Analysis, 25(5): 762-788. https://doi.org/10.1108/IJOA-11-2016-1079

[64] Guerci, M., Carollo, L. (2016). A paradox view on green human resource management: insights from the Italian context. The International Journal of Human Resource Management, 27(2):

212-238. https://doi.org/10.1080/09585192.2015.1033641

[65] Kramar, R. (2014). Beyond strategic human resource management: is sustainable human resource management the next approach? The International Journal of Human Resource Management, 25(8): 10691089. https://doi.org/10.1080/09585192.2013.816863

[66] Saturnino Neto, A., José Chiappetta Jabbour, C., Beatriz Lopes de Sousa Jabbour, A. (2014). Green training supporting eco-innovation in three Brazilian companies: practices and levels of integration. Industrial and Commercial Training, 46(7): 387-392. https://doi.org/10.1108/ICT-02-2014-0010

[67] Yu, W., Chavez, R., Feng, M.Y., Wong, C.Y. (2019). Green human resource management and environmental cooperation: An ability-motivation- opportunity and contingency perspective. International Journal of Production Economics, 219: 224-235. https://doi.org/10.1016/j.ijpe.2019.06.013

[68] Singh, S.K., Del Giudice, M., Chierici, R., Graziano, D. (2020). Green innovation and environmental performance: The role of green transformational leadership and green human resource management. Technological Forecasting and Social Change, 150: 119762. https://doi.org/10.1016/j.techfore.2019.119762

[69] Yusliza, M.Y., Othman, N.Z., Jabbour, C.J.C. (2017). Deciphering the implementation of green human resource management in an emerging economy. Journal of Management Development, 36(10): 1230-1246. https://doi.org/10.1108/JMD-01-2017-0027

[70] Yong, J.Y., Mohd-Yusoff, Y. (2016). Studying the influence of strategic human resource competencies on the adoption of green human resource management practices. Industrial and Commercial Training, 48(8): 416-422. https://doi.org/10.1108/ICT-03-2016-0017

[71] Sawang, S., Kivits, R.A. (2014). Greener workplace: understanding senior management's adoption decisions through the Theory of Planned Behaviour. Australasian Journal of Environmental Management, 21(1): 22-36. https://doi.org/10.1080/14486563.2013.848418

[72] Rangarajan, N., Rahm, D. (2011). Greening human resources: A survey of city-level initiatives. Review of Public Personnel Administration, 31(3): 227-247. https://doi/abs/10.1177/0734371X11408706

[73] Yong, J.Y., Yusliza, M.Y., Ramayah, T., Jabbour, C.J.C., Sehnem, S., Mani, V. (2020). Pathways towards sustainability in manufacturing organizations: Empirical evidence on the role of green human resource management. Business Strategy and the Environment, 29(1): 212-228. https://doi.org/10.1002/bse.2359

[74] Jerónimo, H.M., Henriques, P.L., de Lacerda, T.C., da Silva, F.P., Vieira, P.R. (2020). Going green and sustainable: The influence of green HR practices on the organizational rationale for sustainability. Journal of Business $\quad$ Research, 112: 413-421. https://doi.org/10.1016/j.jbusres.2019.11.036

[75] Pham, N.T., Tučková, Z., Chiappetta Jabbour, C.J. (2019). Greening the hospitality industry: How do green human resource management practices influence organizational citizenship behavior in hotels? A mixedmethods study. Tourism Management, 72: 386-399. https://doi.org/10.1016/j.tourman.2018.12.008

[76] da Silva, M.A.B., da Costa, P.R., Claudia, T.K. (2019). Environmental training and developing individual environmental sustainability competences in Brazilian chemical sector companies. Industrial and Commercial Training, 51(1): 40-51. https://doi.org/10.1108/ICT-122017-0105

[77] Al Kerdawy, M.M.A. (2019). The role of corporate support for employee volunteering in strengthening the impact of green human resource management practices on corporate social responsibility in the Egyptian firms. European Management Review, 16(4): 1079-1095. https://doi.org/10.1111/emre.12310

[78] Chaudhary, R. (2019). Effects of green human resource management: Testing a moderated mediation model. International Journal of Productivity and Performance Management, ahead-of-print(ahead-of-print). https://doi.org/10.1108/IJPPM-11-2018-0384

[79] Luu, T.T. (2018). Employees' green recovery performance: The roles of green HR practices and serving culture. Journal of Sustainable Tourism, 26(8): 1308-1324. https://doi.org/10.1080/09669582.2018.1443113

[80] Bombiak, E., Marciniuk-Kluska, A. (2018). Green human resource management as a tool for the sustainable development of enterprises, polish young company experience. $\quad$ Sustainability, 10(6): 1739. https://doi.org/10.3390/su10061739

[81] Aragão Claudia, G., Jabbour Charbel Jose, C. (2017). Green training for sustainable procurement? Insights from the Brazilian public sector. Industrial and Commercial Training, 49(1): 48-54. https://doi.org/10.1108/ICT-07-2016-0043

[82] Bangwal, D., Tiwari, P., Chamola, P. (2017). Green HRM, work-life and environment performance. International Journal of Environment, Workplace and Employment, 4(3): 244. https://doi.org/10.1504/IJEWE.2017.087808

[83] Nejati, M., Rabiei, S., Chiappetta Jabbour, C.J. (2017). Envisioning the invisible: Understanding the synergy between green human resource management and green supply chain management in manufacturing firms in Iran in light of the moderating effect of employees' resistance to change. Journal of Cleaner Production, 168: 163-172. 
https://doi.org/10.1016/j.jclepro.2017.08.213

[84] Gholami, H., Rezaei, G., Saman, M.Z.M., Sharif, S., Zakuan, N. (2016). State-of-the-art Green HRM System: sustainability in the sports center in Malaysia using a multi-methods approach and opportunities for future research. Journal of Cleaner Production, 124: 142-163. https://doi.org/10.1016/j.jclepro.2016.02.105

[85] Guerci, M., Montanari, F., Scapolan, A., Epifanio, A. (2016). Green and nongreen recruitment practices for attracting job applicants: exploring independent and interactive effects. The International Journal of Human Resource Management, 27(2): 129-150. https://doi.org/10.1080/09585192.2015.1062040

[86] O'Donohue, W., Torugsa, N. (2016). The moderating effect of 'Green' HRM on the association between proactive environmental management and financial performance in small firms. The International Journal of Human Resource Management, 27(2): 239-261. https://doi.org/10.1080/09585192.2015.1063078

[87] Zibarras, L.D., Coan, P. (2015). HRM practices used to promote pro-environmental behavior: A UK survey. The International Journal of Human Resource Management, 26(16):

2121-2142 https://doi.org/10.1080/09585192.2014.972429

[88] Wagner, M. (2013). 'Green' human resource benefits: do they matter as determinants of environmental management system implementation? Journal of
Business
Ethics,
114(3):
443-456.

https://doi.org/10.1007/s10551-012-1356-9

[89] Daily Bonnie, F. (2012). The role of training and empowerment in environmental performance. International Journal of Operations \&amp; Production Management, 32(5): 631-647. https://doi.org/10.1108/01443571211226524

[90] Carmona-Moreno, E., Céspedes-Lorente, J., Martinezdel-Rio, J. (2012). Environmental human resource management and competitive advantage. Management Research: Journal of the Iberoamerican Academy of Management, $10(2)$ : https://doi.org/10.1108/1536-541211251607

125-142.

[91] Gantman, E.R., Yousfi, H., Alcadipani, R. (2015). Challenging Anglo-Saxon dominance in management and organizational knowledge. Revista de Administração de Empresas, 55(2): 126-129. http://dx.doi.org/10.1590/S0034-759020150202

[92] Creswell, J.W., Creswell, J.D. (2017). Research design: Qualitative, quantitative, and mixed methods approaches. 2017: Sage publications. research-design-ceil.pdf (drbrambedkarcollege.ac.in).

[93] Brian R. Keeble BSc MBBS MRCGP. (1988). The Brundtland report: 'Our common future'. Medicine and War, 4(1): 17-25. 